\section{Armed conflict, terrorism, and the allocation of foreign aid}

\section{Piotr Lis}

$\mathrm{F}$

oreign aid is often said to be targeted at promoting economic growth and social development, which in turn are likely to depend on the existence of peace and stability. ${ }^{1}$ Yet donors may be deterred from providing aid because latent and actual conflicts are often accompanied by internal tensions that may increase the risk of corruption associated with the spending of aid, and the destruction of physical and human capital stock may directly disturb commercial interests of foreign donors. In addition, if there are two or more competing political groups within a country, foreign donors may be afraid of being accused of interfering in internal politics by supporting any one of them. This makes political violence potential determinants of aid flows and ones that are generally not considered in the aid literature. The occurrence of armed conflict or of terrorism is therefore likely to hinder economic development and may well reduce the potential effectiveness of foreign aid. ${ }^{2}$

Some scholars argue that the effect of foreign aid on development is not the main determinant of aid allocation, that donors take a number of factors into consideration, including strategic interests and colonial past. One potential strategic goal for donors can be aiding regimes adversely affected by terrorism, possibly as a reimbursement for counter-terrorism efforts. In the resulting principal-agent relation, the donor wants the receiving government to contain terrorism before it spreads to the donor's homeland or affects its interests elsewhere. Indeed, it has been suggested from a theoretical perspective that it would be sensible policy for states with global interests to offer preventive measures, through counter terrorism-oriented tied aid, to countries where transnational terrorist organizations reside, and some find evidence that increased assistance does lead to reduced levels of terror events originating from the receiving country. ${ }^{3}$

This article considers the causal effect of armed conflict and terrorism on aid, using data for a panel of countries. It distinguishes between bilateral and multilateral aid. Multilateral aid is likely to be more responsive to the quality of government and its policies in the receiving countries, and to promote military expenditure reductions, with intergovernmental institutions being less influenced by commercial interests, strategic alliances, and geopolitical or historical considerations. In contrast, bilateral donors are more likely to be influenced by any such factors and are more likely to use aid as a tool for combating terrorism. Another issue to be considered is whether the determinants of aid flows to oil exporters are different, given how important their stability is for the world economy. ${ }^{4}$

A large body of literature discusses the determinants of the distribution of foreign aid and its effects on socio-economic development. Recently, studies have focused on the effect of instability in receiving states on aid flows. One such study finds that violent instability (coups, civil wars, guerrilla warfare, riots, strikes, and the like) had a positive effect on aid allocation. But it also suggests the existence of an inverted-U relation where, on the one hand, low levels of instability result in increased aid as donors attempt to safeguard their interests

and, on the other hand, increasing instability poses a threat to donors' interests and persuades them to shift their attention to more stable countries. Some studies use game theoretic models. These allow aid to be conditioned on the undertaking of counter-terrorism efforts by receiving governments. In a 2011 study, Bandyopadhay, Sandler, and Younas note that a recipient's efforts can demonstrate substitutability with a donor's own counter-terrorism measures, intended to thwart transnationa terrorism at its origin. Nonetheless, count terrorism-tied aid may result in protests and internal unrest in the receiving country, and if the regime becomes sufficiently weakened, its ability to fight against terrorism may become limited, and the threat to both the donor and recipient may rise. Estimating an attack supply curve, Jean-Paul Azam and his co-authors find that increased aid leads to reduced levels of terrorism originating from the receiving country. Unfortunately, their models do not allow for the possibility of a reverse relationship, one in which terrorism determines aid levels, and this is the hypothesis investigated in this article. ${ }^{5}$

\section{Method and data}

Data for the study covers 161 recipient countries from 1973 to 2007 and is drawn from a number of sources. Aid per capita is based on the Project-Level Aid 1.9.1 database, made available by AidData.org. This includes development finance in the form of loans or grants from governments, aid agencies, and intergovernmental organizations. Population, real GDP per capita, and country openness are drawn from the Penn World Table Version 6.3. Because previous studies show a relation between aid and recipients' level of civil liberties and democracy, the Freedom House's Civil Liberties Index is used. This grades states on a scale from one (free) to seven (not free). Terrorism event data comes from ITERATE and from the Global Terrorism Database (GTD). ITERATE includes only transnational events. In contrast, GTD contains transnational and domestic terror events. Using both measures should help 
to distinguish, at least to some extent, the effects of the two types of terrorism. Between 1973 and 2007, ITERATE and GTD recorded 11,506 and 78,762 events, respectively. ${ }^{6}$ Assuming that both track transnational incidents in an adequate manner, the overwhelming majority of attacks in GTD should stem from domestic terrorism events. Indeed, it is estimated that only around 14 percent of events recorded in GTD constitute transnational terrorism. Finally, data on armed conflicts is taken from the UCDP/PRIO Armed Conflict Dataset Version 4-2009.'

The empirical analysis is based on two-way panel data estimation. The choice of this method is motivated by related literature. ${ }^{8}$ The estimated model has the following form:

$$
\begin{aligned}
\ln (A I D)_{\mathrm{i}, \mathrm{t}}= & \alpha+\alpha_{\mathrm{i}}+\alpha_{\mathrm{t}}+\beta_{1} \ln P_{\mathrm{i}, \mathrm{t}-1}+\beta_{2} X_{\mathrm{i}, \mathrm{t}-1}+ \\
& \beta_{3} T_{\mathrm{i}, \mathrm{t}-1}+\beta_{4}\left(T_{\mathrm{i}, \mathrm{t}-1}\right)^{2}+\beta_{5} C_{\mathrm{i}, \mathrm{t}-1}+\beta_{6} L_{\mathrm{i}, \mathrm{t}-1}+\epsilon_{\mathrm{i}, \mathrm{t}}
\end{aligned}
$$

AID is aid per capita received by a recipient $i$ in year $t$. The coefficients $\alpha_{\mathrm{i}}$ and $\alpha_{\mathrm{t}}$ denote recipient-specific and year-specific effects, respectively. $X_{\mathrm{i}, \mathrm{t}-1}$ represents recipients' economic variables, i.e., GDP per capita in constant dollars and economic openness. The latter is measured as the sum of recipients' exports and imports as a share of GDP. $L_{\mathrm{i}, \mathrm{t}-1}$ represents Freedom House's Civil Liberties Index. The choice of explanatory socio-economic conditions such as population, income, economic openness, and level of democracy is motivated largely by the findings of earlier studies. ${ }^{9}$ The number of terrorism incidents per capita in a receiving country is denoted by $T_{\mathrm{i}, \mathrm{t}-1}$, while $C_{\mathrm{i}, \mathrm{t}-1}$ is an indicator variable taking a value of 1 in the presence of non-terrorist armed conflict (e.g., war or civil war) in country $i$ and period $t-1$, and 0 otherwise. Finally, $\epsilon_{\mathrm{i}, \mathrm{t}}$ stands for the error term.

This is a reduced form model and therefore should not be interpreted purely in either demand or supply terms. Panel data methods are used. This means dealing with a number of potential issues. One is heterogeneity across countries. This is controlled for by introducing recipient-specific fixed effects which are likely to arise because donors assign different weights to recipients based on characteristics which remain constant over time, for instance colonial ties, geographical location, or landmass. In addition, time effects are allowed for which may arise because aid allocation decisions are typically made every year and can be affected by global economic cycles.

A second issue is endogeneity. One cannot rule out some beneficial influence of foreign aid in stabilizing societies or inducing recipient governments to take more effective counter-terrorism measures. Thus, aid could help governments to satisfy the needs of dissident interest groups, and the resulting improved economic growth could increase the opportunity cost of joining rebel or terrorist organizations while increased military and security expenditure could make successful atrocities less likely. Yet aid could also lead to increased violence by raising potential gains to rebels from taking over the government and make the receiving government appear as serving foreign interests, leading to social unrest and destabilization. To deal with this potential problem, all explanatory variables are lagged by one year. Foreign aid in a current year cannot affect earlier years' volume of terrorist attacks or number of armed conflicts. An additional benefit is that lags capture the aid allocation dynamics of donors' budget planning procedure, which takes place in advance. Finally, the estimates are based on yearly observations. Averaging observations over longer periods could blur the measured effects of conflict or terrorism. ${ }^{10}$

Results

Non-oil exporters

Table 1 presents the estimates for the effects of terrorism and armed conflict on aid to non-oil exporting countries. The first two columns show results for bilateral aid and the next two for multilateral aid. The ITERATE data is considered to represent transnational terrorism events and the GTD estimates domestic terrorism. The coefficient estimates for the non-conflict variables are generally consistent with expectations, with larger countries tending to get shares of foreign aid that are lower than their populations might suggest (although this effect is only marginally significant for bilateral aid). Aid is increasing in GDP (income) but at a decreasing rate, as donors tend to favor poorer countries with the exception of a number of the poorest states, which are likely to have very limited ability to use received aid efficiently. Donors also seem to reward economic openness. The evidence on civil liberties is mixed, with bilateral donors favoring freer countries, but there is no such drive among multilateral donors. This latter finding is in line with Chauvet (2003).

Terrorism and armed conflict appear to have opposing effects on the allocation of bilateral aid. The results shown in column 1 suggest that countries suffering from transnational terrorism can count on increased assistance, and the positive coefficient on the squared log of transnational attacks per capita indicates increasing aid. This suggests that countries experiencing high levels of transnational terrorism may hope for a proportionally larger increase in bilateral aid when faced with additional attacks. This is consistent with the principal-agent framework in which aid constitutes a reimbursement for recipient's efforts to fight terrorism. As donor's defensive counterterrorism measures increase security at home, they may induce terrorist organizations to seek softer targets in other countries, making the donor's assets abroad more vulnerable. Thus, to protect its political and economic interests, a donor may try to convince other states to exert more counter-terrorism efforts. One way to do this may be through conditional aid, but a test of this hypothesis is not practical as it is not possible to establish how much aid is conditioned on fighting terrorism. Even aid that is not explicitly tied to counter-terrorism can contribute to the eradication of terrorism, by improving the economy and the population's living conditions and so increasing the opportunity cost of joining terrorist groups. Other scholars offer similar reasoning, relating terrorism to a lack of economic opportunities. ${ }^{11}$ 
Table 1: Foreign aid: The effects of armed conflict and terrorism (non-oil exporters, two-way panel estimates, recipient-specific effects)

\begin{tabular}{lllll} 
& Bilateral aid & \multicolumn{3}{l}{ Multilateral aid } \\
& $(1)$ & $(2)$ & $(3)$ & $(4)$ \\
Terrorism dataset & ITERATE & GTD & ITERATE & GTD \\
& & & & \\
Ln(population) & -0.31 & -0.33 & $-1.05^{* *}$ & $-1.20^{* * *}$ \\
& $(0.36)$ & $(0.37)$ & $(0.43)$ & $(0.42)$ \\
Ln(GDP per capita) & $8.37^{* * *}$ & $8.36^{* * *}$ & $13.55^{* * *}$ & $13.47^{* * *}$ \\
& $(1.11)$ & $(1.13)$ & $(1.44)$ & $(1.43)$ \\
Squared ln(GDP per capita) & $-0.56^{* * *}$ & $-0.56^{* * *}$ & $-0.88^{* * *}$ & $-0.88^{* * *}$ \\
& $(0.07)$ & $(0.07)$ & $(0.09)$ & $(0.09)$ \\
Ln(Openness) & $0.36^{* * *}$ & $0.38^{* * *}$ & $0.52^{* * *}$ & $0.50^{* * *}$ \\
& $(0.09)$ & $(0.09)$ & $(0.12)$ & $(0.13)$ \\
Ln(Attacks per capita) & $0.79^{* *}$ & 0.10 & -0.72 & $-0.48^{* * *}$ \\
& $(0.37)$ & $(0.18)$ & $(0.58)$ & $(0.15)$ \\
Squared Ln(Attacks per capita) & $0.03^{* *}$ & 0.00 & -0.03 & $-0.02^{* * *}$ \\
& $(0.01)$ & $(0.01)$ & $(0.02)$ & $(0.00)$ \\
Conflict & $-0.30^{* * *}$ & $-0.32^{* * *}$ & $-0.80^{* * *}$ & $-0.77^{* * *}$ \\
& $(0.08)$ & $(0.08)$ & $(0.12)$ & $(0.13)$ \\
Civil liberties ${ }^{\text {a }}$ & $-0.14^{* * *}$ & $-0.15^{* * *}$ & -0.06 & $-0.07^{*}$ \\
& $(0.03)$ & $(0.03)$ & $(0.04)$ & $(0.04)$ \\
Observations ${ }^{b}$ & 4,027 & 3,893 & 3,993 & 3,860 \\
R-squared & 0.62 & 0.62 & 0.57 & 0.57
\end{tabular}

Notes: All explanatory variables lagged by one period. Robust standard errors in parentheses. All numbers rounded to two decimal places. ${ }^{\text {a }}$ Scale from 1 (free) to 7 (not free). ${ }^{\mathrm{b}}$ The difference in the number of observations between ITERATE and GTD is caused by GTD missing records for 1993 . *** $\mathrm{p}<0.01$, ** $\mathrm{p}<0.05$, * $\mathrm{p}<0.1$.

In contrast, the estimates in column 2 of Table 1 suggest that bilateral donors may be insensitive to domestic terrorism, suggesting that they perceive the risk of attacks spreading to their homelands or interests to be much lower than that associated with transnational terrorism. This should be interpreted cautiously, however, as GTD includes transnational attacks. In addition, any global database is likely to miss a number of domestic attacks as they may not be captured in the global media. Furthermore, nondemocratic regimes may find it relatively easy to suppress information on such events. Bilateral donors do, however, appear to be conflict-averse, with armed conflict in an aid-receiving country reducing bilateral aid by nearly one-third, ceteris paribus. This suggests that a relatively low risk of a conflict spreading to donor countries reduces the incentive to support conflict
Table 2: Foreign aid: The effects of armed conflict and terrorism (oil exporters, two-way panel estimates)

\begin{tabular}{lllll} 
& \multicolumn{2}{l}{ Bilateral aid } & \multicolumn{2}{l}{ Multilateral aid } \\
& $(1)$ & $(2)$ & $(3)$ & $(4)$ \\
Terrorism dataset & ITERATE & GTD & ITERATE & GTD \\
& & & & \\
Ln(population) & $-2.15^{* *}$ & $-2.27^{* *}$ & $-4.51^{* * *}$ & $-4.71^{* * *}$ \\
& $(1.02)$ & $(1.05)$ & $(0.84)$ & $(0.88)$ \\
Ln(GDP per capita) & 3.34 & 2.96 & $-13.96^{* * *}$ & $-13.64^{* * *}$ \\
& $(4.13)$ & $(4.23)$ & $(4.24)$ & $(4.34)$ \\
Squared ln(GDP per capita) & -0.24 & -0.23 & $0.64^{* * *}$ & $0.61^{* * *}$ \\
& $(0.22)$ & $(0.23)$ & $(0.22)$ & $(0.23)$ \\
Ln(Oil exports) & $0.22^{* * *}$ & $0.23^{* * *}$ & 0.06 & 0.05 \\
& $(0.07)$ & $(0.08)$ & $(0.11)$ & $(0.11)$ \\
Ln(Openness) & 0.05 & 0.26 & 0.30 & 0.47 \\
& $(0.70)$ & $(0.74)$ & $(0.69)$ & $(0.70)$ \\
Ln(Attacks per capita) & -0.08 & -0.01 & $-0.08^{*}$ & -0.03 \\
& $(0.05)$ & $(0.05)$ & $(0.05)$ & $(0.05)$ \\
Conflict & -0.53 & -0.58 & $-0.75^{* *}$ & $-0.76^{*}$ \\
& $(0.54)$ & $(0.48)$ & $(0.38)$ & $(0.41)$ \\
Civil liberties ${ }^{\text {a }}$ & -0.16 & 0.13 & 0.17 & 0.24 \\
& $(0.15)$ & $(0.16)$ & $(0.15)$ & $(0.16)$ \\
Observations $^{\mathrm{b}}$ & 500 & 487 & 500 & 488 \\
R-squared & 0.58 & 0.58 & 0.69 & 0.69
\end{tabular}

Notes: All explanatory variables lagged by one period. Robust standard errors in parentheses. All numbers rounded to two decimal places. ${ }^{\text {a }}$ Scale from 1 (free) to 7 (not free). ${ }^{\mathrm{b}}$ The difference in the number of observations between ITERATE and GTD is caused by GTD missing records for 1993 . *** $\mathrm{p}<0.01$, ** $\mathrm{p}<0.05$, * $\mathrm{p}<0.1$.

resolution efforts within countries or that aid reductions may be intended to exert pressure on governments to be more accountable. This can also reflect worries over an excessive influence of exploitative military strongmen. ${ }^{12}$ Cutting aid to troubled recipients, and shifting it to peaceful ones, may be intended to show the benefits of maintaining social peace and stability.

Multilateral aid flows are not affected by transnational terrorism, as measured by ITERATE (column 3), but they seem to show a significant and negative response to domestic terrorism (column 4). They are very strongly affected by armed conflict, with a conflict-affected country likely to see a reduction of around 80 percent in received aid. There are a number of possible explanations for this. Multilateral donors are less likely to heed geopolitical interests than bilateral ones and pay more attention 
to the efficient use of aid as well as the promotion of economic and social development. Consequently, they tend to limit assistance to countries affected by terrorism and armed conflict. As some scholars show, violent instability significantly reduces economic growth, and this is likely to be associated with smaller investment, poorer policies, and higher risks of resource misuse. For example, Gaibulloev and Sandler (2009) put the effect of armed conflict at twice the size of the impact of terrorism, and so multinational agencies may be inclined to use aid as a tool in the promotion of peace and stability, punishing violent states and rewarding those that find peaceful solutions. They may also be less sensitive to transnational terrorism as it occurs less frequently (and thus is less destructive than domestic terrorism), poses a lesser threat to the efficient use of aid, and affects their own citizens to a lesser degree. However, decisions of multilateral institutions are of course affected by member governments. Mallaby (2002) argues, for instance, that in spite of being multinational in principle, both the World Bank and the International Monetary Fund reflect the thinking and priorities of the United States, a country that is the target of about 40 percent of all transnational attacks. ${ }^{13}$

Oil exporters

One issue that has not been considered in the literature concerns the treatment of oilexporting countries. Effects may differ, relative to non-oil exporting countries, because of donors' interest in the stability of oil exporters. Table 2 shows that bilateral and multilateral donors respond in different ways to recipient characteristics. The recipients' income per capita is not important for bilateral donors, but multilateral donors react to increases in income with aid cuts. As expected, multinational organizations are not influenced by the size of oil exports, while bilateral donors reward a one percent increase in oil exports (valued in constant 2005 dollars) with around a 0.22 percent rise in aid.

Surprisingly, despite the common perception that oil importers are ready to provide assistance to ensure stability of oil-producing regimes, bilateral donors appear to be neutral to terrorism and armed conflict occurring in oil-exporting countries. It is possible that bilateral donors do not want to appear to be supporting nondemocratic regimes in exchange for oil, but to investigate this would require donor-by-donor case studies. Multilateral donors, free of strategic interests, are consistent in their aversion to armed conflict, reducing multilateral aid to an oil exporter by approximately 75 percent. But there is no evidence that they react to terrorism. Although the coefficients are negative, only the estimate on ITERATE is marginally statistically significant.

\section{Conclusions}

This article considers the effects of armed conflict and terrorism on bilateral and multilateral aid flows by analyzing a panel of aid recipients. It adds to the literature that considers foreign aid as a means of engaging countries that are sources of terrorism in the fight against this security threat. ${ }^{14}$ The empirical results show that with the exception of bilateral assistance to oil-exporting states, armed conflict has a strong negative effect on foreign aid receipts. However, bilateral and multilateral donors seem to differ in their reactions to terrorism. Episodes of transnational terrorism are associated with increased bilateral aid, while donor countries do not seem to be sensitive to domestic terrorism. In contrast, multilateral donors appear to react strongly to domestic terrorism by reducing aid flows, but remain indifferent to transnational terrorism. Thus, this article adds to the evidence that bilateral donors may use foreign aid as a tool in pursuing strategic interests, highlighted by their focus on the size of oil exports when allocating aid to oil-exporting states.

The findings of this study lead to policy implications for aid-receiving nations. To ensure optimal aid, they should intensify their conflict-resolution efforts. This is particularly important for countries relying on multilateral aid which can be cut by up to 80 percent in response to armed conflict. Given that receiving nations react to such incentives, aid can have peace-promoting effects. The type of aid may also influence receiving governments' reactions to terrorism. For countries reliant on multinational assistance, there seems to exist no additional aid-related benefit in combating transnational terrorism. However, multilateral donors are likely to reward a reduction in domestic terrorism, thus increasing the potential payoffs from efforts to combat this type of violence.

The policy implications appear to be very different for countries that rely on bilateral aid. Since donor countries are more likely to pursue their own strategic goals, it seems sensible for recipients to align themselves with the interests of donor nations. One such goals is to combat transnational terrorism, whereby a donor may use aid to convince other states to participate in the fight against transnational terrorism. The empirical results suggest that a country affected by transnational terrorism is likely to receive a disproportionately large amount of aid. Although it seems right that some states get more aid because they face more complicated threats than others, there is a danger of creating perverse incentives for a receiving government to exert effort below the level desired by the donor in order to maintain the terrorism threat at a level that ensures its desired level of aid receipts. This serves as a warning for donor governments to develop a cautious approach when designing incentives for other nations to engage in counter-terrorism activities. They should introduce clear conditions and targets for the receipt of bilateral aid and consider implementing safeguards so as not to inadvertently instigate more violence in aid-receiving nations.

The analysis reported here shows how international aid flows respond to terrorism and armed conflict. Although it has shed some light on the relation between these variables, a number of questions are left to future research. For example, because the two categories of aid are associated with different policy implications, it would be of interest to learn how effectively recipients dependent on either bilateral or multilateral aid respond to transnational and domestic terrorism. Future studies should also look 
(C) www.epsjournal.org.uk - Vol. 8, No. 1 (2013)

at micro-level changes in aid allocation in the presence of political violence.

Notes

Piotr Lis is Lecturer in Economics at Coventry University in the United Kingdom. He may be reached at <Piotr.Lis@coventry.ac.uk>.

1. Blomberg, Hess, and Orphanides (2004); Gaibulloev and Sandler (2009).

2. Collier (2006). Terrorism is a form of armed conflict of course but conventionally understood to be different from armed conflict such as interstate war and civil war.

3. A number of factors: Burnside and Dollar (2000); Alesina and Dollar (2000). Reimbursement and sensible policy: Bandyopadhyay, Sandler, and Younas (2011). Evidence: Azam and Thelen (2008).

4. Multilateral: Boyce and Pastor (1998). Bilateral aid and oil markets: Yergin (2006).

5. Inverted-U: Chauvet (2003). Game-theoretic: For example, Mandler and Spagat (2003); Bandyopadhay, Sandler, and Younas (2011). Azam and co-authors: Azam and Delacroix (2006); Azam and Thelen (2008).

6. The GTD dataset is missing records for 1993. This is reflected in a lower number of observations used in the following GTD regressions.

7. Aid per capita data: Nielson, Powers, and Tierney (2010). Penn World Tables: Heston, Summers, and Aten (2009). Civil liberties and index: For instance, Alesina and Dollar (2000); Chauvet (2003); Freedom House (2010). ITERATE: Mickolus, Sandler, et al. (2008); GTD: Global Terrorism Database (START 2011). The number of terrorist attacks is normalized by recipients' population. This is justified by the fact that ten attacks in a country of 100 million should have a smaller economic impact than the same number of attacks in a country of five million. On ITERATE and GTD, see, e.g., Gaibulloev and Sandler (2009). 14 percent: Kis-Katos, Liebert, and Schulze (2011). Armed conflict data: Gleditsch, et al. (2002).

8. Trumbull and Wall (1994); Alesina and Dollar (2000); Alesina and Weder (2002); Chauvet (2003); Blomberg, Hess, and Orphanides (2004); Gaibulloev and Sandler (2009).

9. In particular Alesina and Dollar (2000); Alesina and Weder (2002); and Chauvet (2003).
10. Recipient-specific fixed effects: Frees (2004). Aid and decreased violence: Collier and Hoeffler (2000). Aid and increased violence: Bandyopadhyay, Sandler, and Younas (2011). Use of lagged values: An outbreak of violence in one year could result in a reduction in received aid; however, if a conflict was mitigated within a year or two, a country could consequently experience higher aid flows designated for reconstruction and as an incentive for maintaining stability. This process would be indistinguishable when using longer periods.

11. Principal-agent framework: Bandyopadhyay, Sandler, Younas (2011). Softer targets: Lis (2011). Other scholars: Blomberg, Hess, and Orphanides. (2004); Bueno de Mesquita (2005).

12. Mallaby (2002).

13. Some scholars show: Blomberg, Hess, and Orphanides (2004); Gaibulloev and Sandler (2009). Punishing violent states: Boyce and Pastor (1998). 40 percent: Enders and Sandler (2006).

14. Azam and Thelen (2008; 2010); Bandyopadhyay, Sandler, and Younas (2011).

\section{References}

Alesina, A. and D. Dollar. 2000. "Who Gives Foreign Aid to Whom and Why?” Journal of Economic Growth. Vol. 5, No. 1, pp. 33-63.

Alesina, A. and B. Weder. 2002. "Do Corrupt Governments Receive Less Foreign Aid?” American Economic Review. Vol. 92, No. 4, pp. 1126-1137.

Azam, J.P. and A. Delacroix. 2006. “Aid and the Delegated Fight Against Terrorism.” Review of Development Economics. Vol. 10, No. 2, pp. 330-344.

Azam, J.P. and V. Thelen. 2008. "The Roles of Foreign Aid and Education in the War on Terror.” Public Choice. (2008)135, pp. 375-397.

Azam, J.P. and V. Thelen. 2010. "Foreign Aid versus Military Intervention in the War on Terror.” Journal of Conflict Resolution. Vol. 54, No. 2, pp. 237-261.

Bandyopadhyay, S., T. Sandler, J. Younas. 2011. "Foreign Aid as Counterterrorism Policy." Oxford Economic Papers. Vol. 63, No. 3, pp. 423-447.

Blomberg, S.B., G.D. Hess, and A. Orphanides. 2004. "The Macroeconomic Consequences of Terrorism.” Journal of Monetary Economics. Vol. 51, No. 5, pp. 1007-1032.

Boyce, J.K. and M. Pastor, Jr. 1998. “Aid for Peace: Can International Financial Institutions Help Prevent Conflict?” World Policy Journal. Vol. 15, No. 2, pp. 42-49.

Bueno de Mesquita, E. 2005. “The Quality of Terror.” American Journal of Political Science. Vol. 49, No. 3, pp. 515-530. 
(C) www.epsjournal.org.uk - Vol. 8, No. 1 (2013)

Burnside, C. and D. Dollar. 2000. “Aid, Policies, and Growth.” American Economic Review. Vol. 90, No. 4, pp. 847-868.

Chauvet, L. 2003. "Socio-Political Instability and the Allocation of International Aid by Donors.” European Journal of Political Economy. Vol. 19, No. 1, pp. 33-59.

Collier, P. 2006. "War and Military Expenditure in Developing Countries and their Consequences for Development.” The Economics of Peace and Security Journal. Vol. 1, No. 1, pp. 10-13.

Collier, P. and A. Hoeffler. 2000. “Aid, Policy and Peace.” Development Research Group. Washington, D.C., World Bank.

Enders, W. and T. Sandler. 2006. "Distribution of Transnational Terrorism Among Countries by Income Class and Geography After 9/11.” International Studies Quarterly. Vol. 50, No. 2, pp. 367-393.

Freedom House. 2010. "Freedom in the World Country Ratings 1972-2009." http://www.freedomhouse.org/report/freedom-world/freedom-world-2010 [accessed 15 September 2012].

Frees, E.W. 2004. Longitudinal and Panel Data: Analysis and Applications in the Social Sciences. New York: Cambridge University Press.

Gaibulloev, K. and T. Sandler. 2009. "The Impact of Terrorism and Conflicts on Growth in Asia.” Economics \& Politics. Vol. 21, No. 3, pp. 359-383.

Gleditsch, N.P., P. Wallensteen, M. Erisksson, M. Sollenberg, and H. Strand. 2002. “Armed Conflict 1946-2001: A New Dataset.” Journal of Peace Research. Vol. 39, No. 5, pp. 615-637.

Heston, A., R. Summers, and B. Aten. 2009. Penn World Table Version 6.3, Center for International Comparisons of Production, Income and Prices at the University of Pennsylvania. August 2009.

Kis-Katos, K., H. Liebert, and G.G. Schulze.(2011. "On the Origin of Domestic and International Terrorism.” European Journal of Political Economy. Vol. 27, Supplement 1, pp. S17-S36.

Lis, P. 2011. "Impact of Selected Historical Events on the Income-Based Distribution of Terrorism from the Rise of Fundamentalist Terrorism to the Iraq War." International Studies Quarterly. Vol. 55, No. 3, pp. 771-785.

Mallaby, S. 2002. "The Reluctant Imperialist: Terrorism, Failed States, and the Case for American Empire.” Foreign Affairs. Vol. 81, No. 2, pp. 2-7.

Mandler, M. and M. Spagat. 2003. "Foreign Aid Designed to Diminish Terrorist Atrocities Can Increase Them.” London: CEPR Discussion Paper No. 4004.

Mickolus, E.F., T. Sandler, et al. 2008. International Terrorism: Attributes of Terrorist Events, 1968-2007. Dunn Loring, VA, Vinyard Software.

Nielson, D.L., R.M. Powers, and M.J. Tierney. 2010. “Broad Trends in Foreign Aid: Insights from PLAID 1.9.1.” Conference paper presented at Aid Transparency and Development Finance: Lessons and Insights from AidData, Oxford, U.K. 22-25 March 2010.

START National Consortium for the Study of Terrorism and Responses to Terrorism.
2011. Global Terrorism Database. Retrived from http://www.start.umd.edu/gtd. Trumbull, W.N. and H.J. Wall. 1994. "Estimating Aid-Allocation Criteria with Panel Data.” The Economic Journal. Vol. 104, No. 425, pp. 876-882.

Yergin, D. 2006. “Ensuring Energy Security.” Foreign Affairs. Vol. 85, No. 2, pp. 69-82. 